\title{
Phylogeny of Iberian Zabrus (Coleoptera: Carabidae: Zabrini) based on mitochondrial DNA sequence
}

\author{
JosÉ-Fermín SÁNCHEZ-GEA, José GALIÁN and José SERRANO* \\ Departamento de Zoología, Facultad de Veterinaria, Universidad de Murcia, Campus de Espinardo, Aptdo. 4021, 30071 Murcia, \\ Spain; e-mails: jfermin@um.es; jgalian@um.es; jserrano@um.es
}

Key words. Molecular phylogeny, mitochondrial COI sequence, karyotype analysis, Zabrus, Carabidae, Coleoptera

\begin{abstract}
The genus Zabrus Clairville, 1806 is a Holomediterranean taxon that radiated into about a hundred species most likely during the Cenozoic. There are four endemic subgenera on the Iberian Peninsula, which include 28 species, Epomidozabrus ( 3 spp.), Euryzabrus (1 sp.), Platyzabrus (2 spp.) and Iberozabrus (22 spp.). A mitochondrial fragment comprising part of the cytochromeoxidase-I, tRNAleu, and part of the cytochrome-oxidase-II genes was sequenced of most of these species. Taxa of other subgenera of Zabrus (Macarozabrus, Polysitus, Zabrus, and Pelor), six species of Amara (the putative sister taxon of Zabrus), and representatives of tribes related to Zabrini were also sequenced. The results show that the genus Zabrus is a monophyletic taxon well separated from Amara. The four subgenera endemic to the Iberian Peninsula also make up a monophyletic clade, which stresses the association between the geographic distribution and the monophyly of many supraspecific taxa within this genus. The species-rich subgenus Iberozabrus seems to be the sister taxon of the clade made up of the three other subgenera endemic to the Iberian Peninsula. The Iberozabrus species-groups proposed by Andújar \& Serrano in 2001, based on morphological and geographical grounds, are only partly corroborated by the molecular phylogeny. The lack of congruence between these data sets is mainly between those speciesgroups with large numbers of species and more complex geographic patterns. Some cases of incongruence are possibly due to homoplasic external characters appeared by convergent evolution.
\end{abstract}

\section{INTRODUCTION}

The genus Zabrus Clairville, 1806 is included in the subfamily Pterostichinae and tribe Zabrini, and comprises about 105 species mostly distributed in the Mediterranean Basin (Andújar \& Serrano, 2001). Ganglbauer (1915) established the current taxonomy of the genus and divided it into subgenera based on the external characters of the adult and geographic distribution of the taxa. Freude (1986) questioned the distinctness of Zabrus from Amara because some of its species occasionally show one of the diagnostic traits of Zabrus. However, a karyotypic analysis (Galián et al., 1991), the localisation of rDNA loci (Sanchéz-Gea et al., 2000), and the structure of the female genitalia (Ortuño et al., 2003) support the monophyly of the genus Zabrus.

Most of the subgenera of Zabrus are endemic to particular areas and are probably monophyletic groups characterised by one or more apomorphies (Andújar \& Serrano, 2000). On the Iberian Peninsula there are four endemic subgenera, namely Euryzabrus (1 species), Platyzabrus (2 species), Epomidozabrus (3 species) and Iberozabrus (22 species), plus two of the three species of the nominal subgenus (Andújar \& Serrano, 2001). Andújar \& Serrano (2001) investigated the phylogenetic relationships of these subgenera using 24 morphological imaginal characters. Most of those characters were phylogenetically uninformative because they are either autapomorphies or homoplasies. In spite of these limitations, it was shown that the subgenera endemic to the Iberian Peninsula make up a monophyletic group separated from the subgenus Zabrus. Likewise each of the subgenera Euryzabrus, Platyzabrus and Epomidozabrus make up monophyletic groups but these are interspersed within the species of the large subgenus Iberozabrus. Moreover, the clades of the species within Iberozabrus do not agree with the species-groups postulated on the basis of the morphological and geographic characters currently used in identification keys. These results indicate that Iberozabrus has a complex evolutionary history, perhaps starting in the Oligocene. As noted by Oosterbroek \& Arntzen (1992), the Mediterranean Basin has undergone drastic changes in sea level, alpine uprisings and climatic oscillations during the last 30-40 MY, when the Tethys Sea started to close. These factors probably exerted major influences on the whole Tethys biota, particularly on the Iberian Peninsula, which became a centre of origin of new taxa, as exemplified by Iberozabrus. Most Iberian Zabrus are flightless and have a poor dispersal ability, which explains the high number of species in mountainous areas. Other species are found in the lowlands or live in sandy coastal habitats (Andújar \& Serrano, 2001). Thus, present day distribution and habitat preferences suggest that the genus has undergone a complex sequence of speciation events in the Iberian Peninsula worthy of investigation, especially in the large subgenus Iberozabrus. The aim of this study is to investigate the phylogeny of Iberian taxa of Zabrus by analysing their mitochondrial DNA, and compare our results with those of Andújar \& Serrano (2001). Sequence data of this molecule has proved useful for phylogenetic studies of many

\footnotetext{
* Corresponding author.
} 
organisms (review in Avise, 2000), including beetles of the family Carabidae (Howland \& Hewitt, 1995; Galián et al., 1999; Emerson et al., 1999, 2000; Martínez et al., in press) to which the genus Zabrus belongs.

\section{MATERIAL AND METHODS}

\section{Material}

Sixty-three individuals of the genus Zabrus were sequenced. The individuals belong to the four subgenera endemic to the Iberian Peninsula, Epomidozabrus, Euryzabrus, Platyzabrus and Iberozabrus, and to the subgenera Zabrus, Macarozabrus, Polysitus and Pelor. Six species of the putative sister taxa of Zabrus, the genera Amara and Curtonotus were also sequenced, and species from other tribes of the subfamily Pterostichinae, which includes the tribe Zabrini, were included as out-groups. Sampling localities are given in Appendix 1. In some cases more than one individual was sequenced to check the influence of intra-specific variation on the results. Body parts of the beetles not used in this study were preserved in $100 \%$ ethanol, and deposited in the collection of the Department of Zoology and Physical Anthropology, University of Murcia, Spain.

\section{DNA extraction}

One or two legs of each individual were used. Total DNA was extracted using a standard lysis buffer $(200 \mu \mathrm{L}$ to $500 \mu \mathrm{L}$ of $1 \mathrm{M}$ Tris- $\mathrm{HCl} \mathrm{pH}=7.4,0.5 \mathrm{M}$ EDTA $\mathrm{pH}=8,10 \%$ SDS $\mathrm{pH}=7.2$ and $10 \mu \mathrm{L} 10 \mathrm{mg} / \mathrm{ml}$ proteinase $\mathrm{K}$ ) or Wilson extraction buffer $(200 \mu \mathrm{L}$ to $500 \mu \mathrm{L}$ of $100 \mathrm{mM}$ Tris- $\mathrm{HCl} \mathrm{pH}=7.4,10 \mathrm{mM}$ EDTA $\mathrm{pH}=8,100 \mathrm{mM} \mathrm{NaCl}$ and $10 \mu \mathrm{L} 10 \mathrm{mg} / \mathrm{ml}$ proteinase $\mathrm{K}$ ). Phenol (Sambrook et al., 1989) and Chelex (Walsh et al., 1991) extraction protocols were assayed.

\section{DNA amplification}

PCR reactions were performed in 12.5 to $25 \mu \mathrm{L}$ volume using Taq DNA Polymerase (Pharmacia Biotech, Little Chalfont, UK) or puRe Taq Ready-To-Go PCR Beads (Amersham Biosciences, Little Chalfont, UK). Two different sets of primers, commonly known as Dick (5'-CCTACAGGAATTAAAGTTTTTAGATGA TTAGC-3') and Pat (3'-ATTATACCGTCTAATCACGTAA CCT-5'), or Dick and Marilyn (3'-GTTACTAT(A/G)ACTTGA ATACT-5') were used. These primers amplify a fragment of mitochondrial DNA that includes the end of cytochrome oxidase I (CO-I), tRNAleu, and the beginning of cytochrome oxidase II (CO-II), as well as the intergenic spacers (Simon et al., 1994).

Cycle parameters were $45 \mathrm{~s}$ denaturalisation at $94^{\circ} \mathrm{C}, 1 \mathrm{~min}$ of annealing at $45-52^{\circ} \mathrm{C}$, and $1 \mathrm{~min}$ extension at $72^{\circ} \mathrm{C}$ for 35 cycles. No purification method was used and DNA amplifications were simply precipitated with $2 / 3$ vol. of $5 \mathrm{M}$ ammonium acetate and 1 vol. of isopropanol.

\section{DNA sequencing}

PCR products were sequenced with the Big Dye TM Terminator Cycle Sequencing Ready Reaction Kit (PE Biosystems, Foster City, California) using Ampli Taq DNA Polymerase FS (Applied Biosystems, Tres Cantos, Madrid, Spain) in an ABI PRISM Tm 377 DNA Sequencer (Applied Biosystems, Tres Cantos, Madrid, Spain). When needed sequencing was performed in both directions using the same primers for amplification.

\section{Alignment and correction of sequences}

Sequences were aligned using ClustalW v. 1.7 (Thomson et al., 1994). Incongruent and missing data insequences were manually corrected using the Chromas program v. 2.22 (Technelysium Pty Ltd 2002). Aligned sequences were checked for a post-correction of gaps. Some bases were disregarded at the beginning and the end of the sequence. The final sequence data set consisted of 876 base pairs: 1-535 for CO-I, 544-611 for tRNAleu and 618-876 for the CO-II. GenBank accession numbers for these sequences are AY551824-AY551904.

\section{Phylogenetic analysis}

The sequence was analysed using the maximum parsimony (MP), maximumlikelihood (ML) and two different distance methods: neighbour joining (NJ) and minimum evolution (ME). Two different programs were used for these analyses: PAUP v. 4.0b10 (Swofford et al., 1996) and MEGA v. 2.0 (Kumar et al., 2001). PAUP was used to perform MP and ML analyses with unweighted and weighted characters. MEGA was used to perform NJ and ME analyses with unweighted characters. MacClade v. 3.0 program (Maddison \& Maddison, 1992) was used to weight the bases of the sequenced mitochondrial fragment.

For distance analyses NJ and ME, pairwise sequence differences were compared using the Kimura 2-parameter method using two different tests of phylogeny: bootstrap (BT) and interior branch (IBT) test, with 10,000 replications in each analysis.

MP analysis was done using heuristic searches and a BT of 10,000 replications (TBR branch swapping, MULPARS option in effect) with simple stepwise addition of taxa, to find the most parsimonious tree. A 50\% majority-rule consensus tree was constructed if more than one parsimonious tree was obtained.

To choose the best possible model to do the ML analysis, Model Test version 3.06 program was used (Posada \& Crandall, 1998). This program tests 56 different models using two criteria: Akaike information criterion (AIC) and hierarchical likelihood ratio tests (hLRTs). After implementing the data matrix with this model, a ML analysis was done using heuristic searches and a BT of 10,000 replications (TBR branch swapping, MULPARS option in effect) with simple stepwise addition of taxa. A 50\% majority-rule consensus tree was constructed when more than one tree was obtained.

\section{RESULTS}

423 bases out of the 876 in the sequence data set were variable and 303 were parsimony informative. Within the tribe Zabrini there were 356 variable sites of which 274 were parsimony informative. For species of the genus Zabrus there were 321 variable sites of which 239 were parsimony informative. All the species of the genus Zabrus are included in a single clade (Fig. 1) supported by values ranging from 72 to 100 depending on the kind of analysis used.

The sequence analysis shows that species of the genus Zabrus have always one or two extra adenines in the intergenic spacer between tRNAleu and the cytochromeoxidase-II, except for those of the subgenus Iberozabrus, which have three extra adenines.

\section{Distance analysis}

The NJ and ME analyses done by the MEGA program using IBT produced similar condensed trees. Three different clades of Zabrus species were obtained at the level of subgenera (Fig. 1). Clade 1 included Eastern Mediterranean taxa (Bulgaria, Greece and Turkey), which are members of the subgenus Pelor. Clade 2 included species of subgenera Zabrus, Macarozabrus and Polysitus. Clade 3 included all species endemic to the Iberian Peninsula. This last clade includes two subclades, clade $3 \mathrm{~b}$, comprising the subgenera Euryzabrus, Epomidozabrus, 


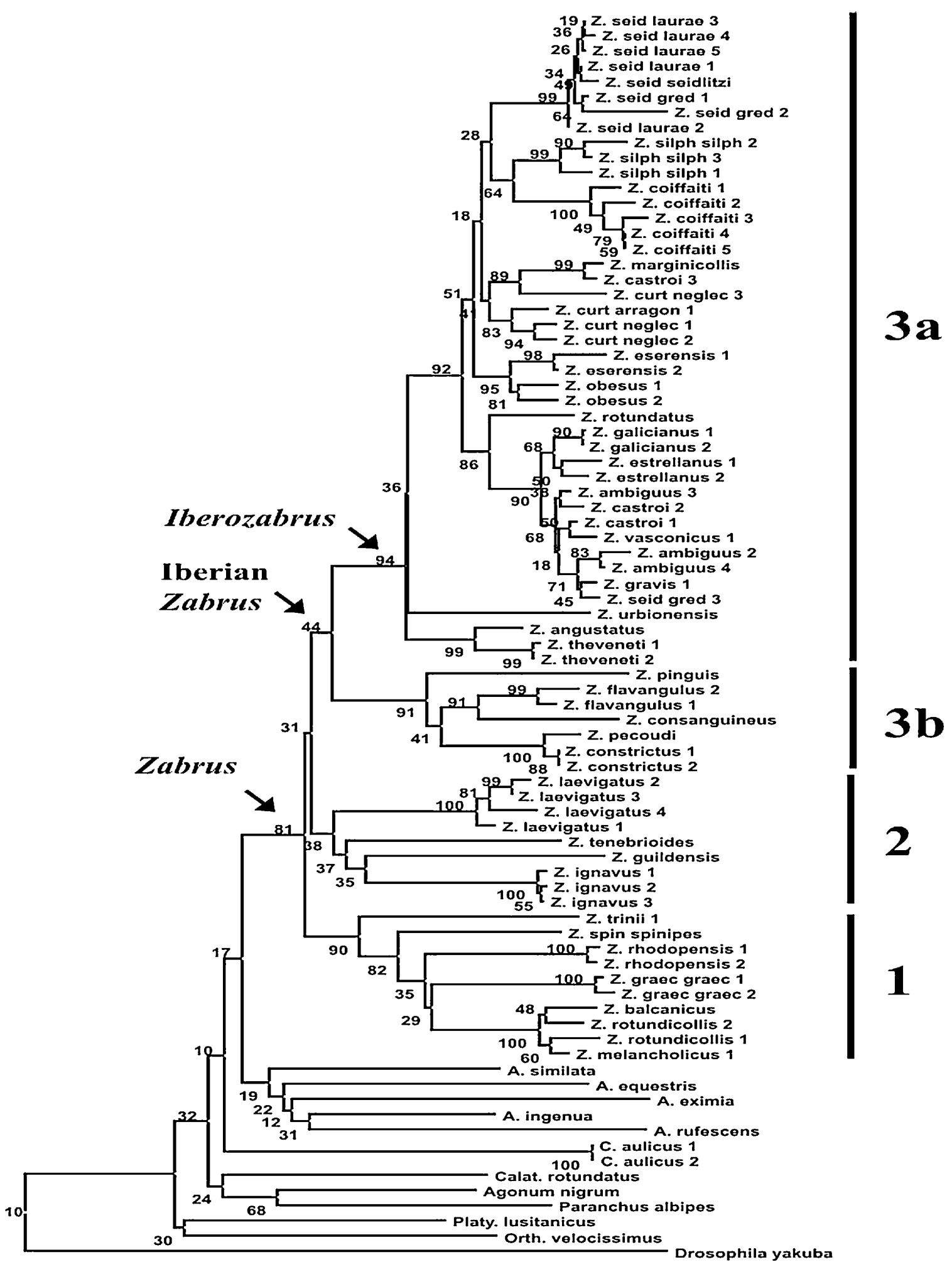

Fig. 1. Minimum evolution interior branch test tree for species of Zabrus and related taxa, based on a mitochondrial DNA fragment of cytochrome-oxidase-I, tRNAleu and cytochrome-oxidase-II. Numbers refer to interior branch test values based on 10,000 replications. Clade 1 = Zabrus subgenus Pelor; clade $2=$ Zabrus subgenera Macarozabrus, Zabrus, and Polysitus; clade 3a $=$ Zabrus subgenus Iberozabrus; clade 3b = Zabrus subgenera Euryzabrus, Epomidozabrus and Platyzabrus.

Platyzabrus and one species of the subgenus Iberozabrus, and clade 3 a the other taxa of Iberozabrus.

The NJ and ME analyses done by the MEGA program using BT also produced similar consensus trees. These consensus trees were less resolved than those obtained using IBT (consensus values were lower) and some clades were resolved as polytomies. Seven different clades were obtained at the level of subgenera (not 


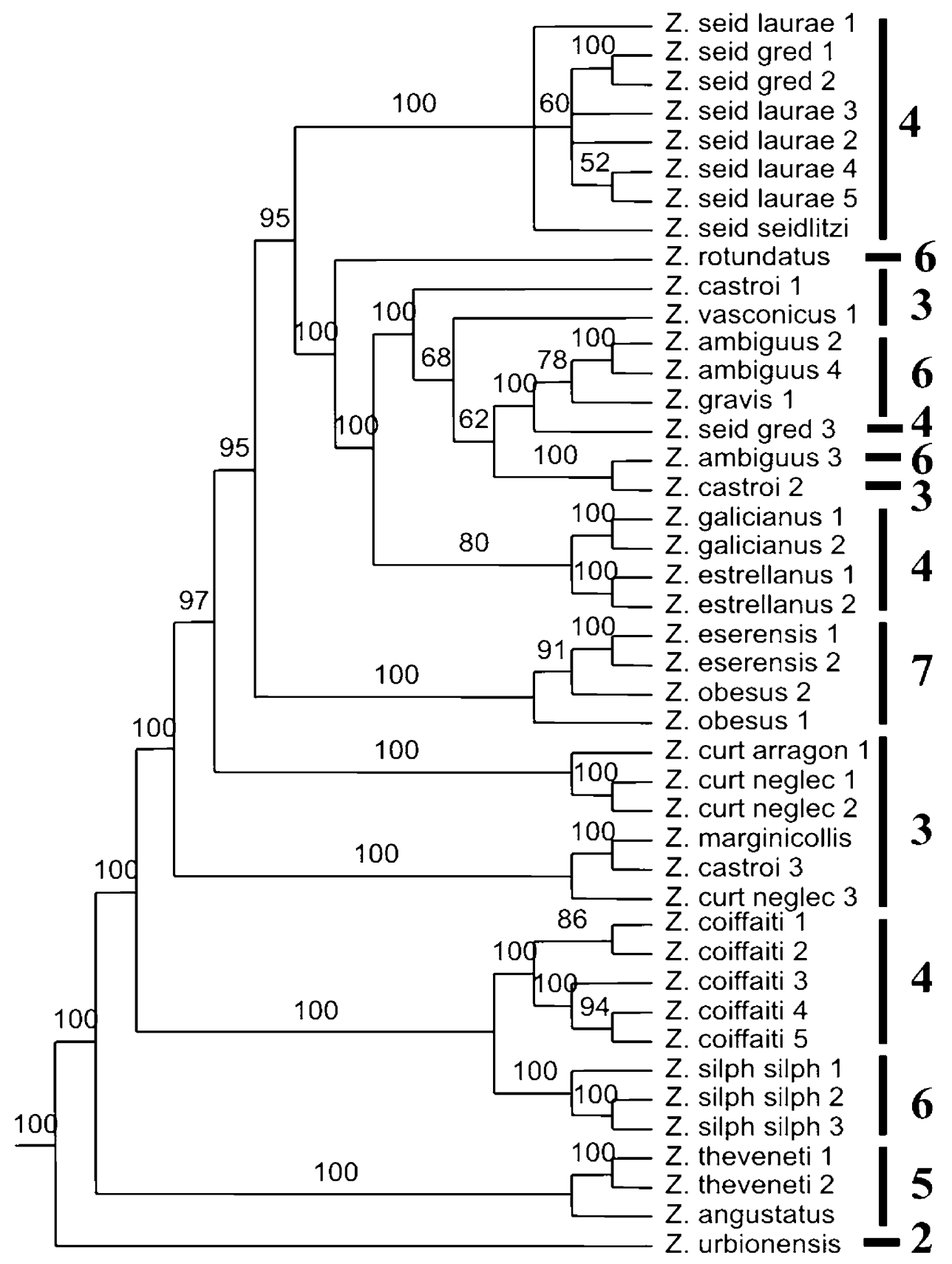

Fig. 2. Fragment of the maximum parsimony bootstrap consensus tree showing only the species of the subgenus Iberozabrus. Unweighted characters based on the same mitochondrial fragment as in Fig. 1. Numbers to the left of each branch refer to the majority rule bootstrap values based on 10,000 replications. Numbers to the right of the reconstructed phylogeny show the speciesgroups to which the species belongs. The seven species-groups are indicated in Appendix 2.

shown). Clade 1 includes all of the East Mediterranean species, as obtained using IBT. Clades 2 to 5 correspond to clade 2 obtained by IBT. Clade 2 includes only one species of the nominal subgenus Zabrus, Z. tenebrioides. Clade 3 includes the species from the Canary Islands, $Z$. (Macarozabrus) laevigatus. Clade 4 includes the Moroccan species of the subgenus Polysitus. Clade 5 includes another species of the subgenus Zabrus, Z. ignavus. Finally, clades 6 and 7 obtained using BT correspond to clade 3 obtained by IBT, and in both cases are unresolved. Clade 6 includes species of the subgenera Euryzabrus, Epomidozabrus, Platyzabrus and Z. (Iberozabrus) consanguineus. Clade 7 includes the rest of the species of the subgenus Iberozabrus, all endemic to the Iberian Peninsula. The subclades of the subgenus Iberozabrus only partly conform with the species-groups postulated for this subgenus on the basis of morphology and geographic distribution (Andújar \& Serrano, 2001).

$\mathrm{NJ}$ and ME analyses produced different arrangement of the clades when using IBT. The NJ analyses indicated that the Iberian Zabrus are more closely related to Eastern Mediterranean taxa than to Zabrus + Macarozabrus + Polysitus, and ME analyses indicated a closer relationship of Iberian taxa to Zabrus + Macarozabrus + Polysitus 


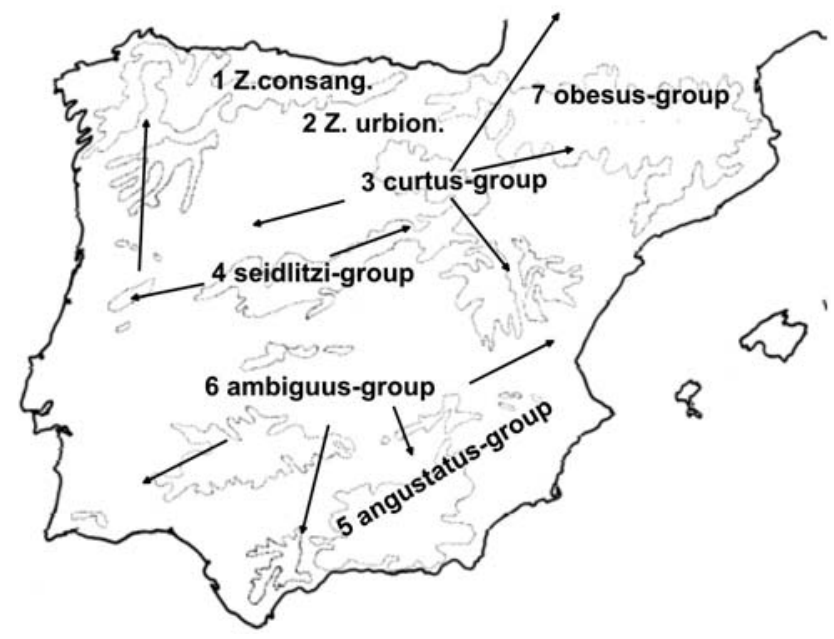

Fig. 3. Map of the Iberian Peninsula showing the location of the Iberozabrus species-groups indicated in Appendix 2.

than to Eastern Mediterranean taxa. However, these relationships are weak as they are only supported by low values.

\section{Maximum likelihood}

Model Test chose TVM $+\mathrm{G}+\mathrm{I}$ as the best model based on AIC and hLRTs criteria with unweighted characters. When bases where assigned weights $2: 5: 1$ Model Test chose TVM $+\mathrm{G}+\mathrm{I}$ under hLRTs criterion, and GTR $+\mathrm{G}$ + I under AIC criterion. The heuristic search analysis performed by PAUP using these models found 1 or 2 trees. The trees had a score of $8,256.72155$ with unweighted characters, and a score of $17,845.95246$ (AIC) or $17,493.10825$ (hLRTs) with weighted characters. The trees had a C.I. of 0.3987 and a R.I. of 0.6888 with unweighted characters, and a C.I. of 0.4497 and a R.I. of 0.6907 with weighted characters.

At the level of subgenera five different clades were obtained in the majority rule consensus tree. These clades matched those obtained using distance methods (NJ and $\mathrm{ME}$ ) (Fig. 1), with the exception of clade 2 where one species of the nominal subgenus Zabrus, Z. tenebrioides, is excluded and is in a clade of its own. The differential weighting of the three codon positions produced no effect at this level.

At the level of species included in each subgenera several subclades are obtained. Some of them that belong to the subgenus Iberozabrus (Fig. 2) partially conform to species-groups derived from morphological and geographic characters, although the rearrangement of these subclades differs from those obtained using distance methods.

\section{Parsimony analysis}

The heuristic search analysis done by PAUP found 9,768 most parsimonious trees when the three bases of each codon where assigned weights of $2: 5: 1$. The trees had a length of 2,906 steps, a C.I. of 0.4604 and a R.I. of 0.7037 . The heuristic search analysis done by PAUP found 40,600 most parsimonious trees when the three bases were assigned equal weights. These trees had a length of 1,496 steps, a C.I. of 0.4051 and a R.I. of 0.6970

In both cases, at the level of subgenera, there were five clades in the majority rule consensus tree. These clades also matched those obtained with distance methods (Fig. 1 ), with the exception of clade 2 . This clade was split into two clades by this analysis, which differ depending on the weighting of the characters. With unweighted characters the first clade is formed by species from Morocco and the Canary Islands (subgenus Polysitus and Macarozabrus, respectively) and the second by the two species of the subgenus Zabrus. With weighted characters species of the subgenus Polysitus were assigned to the second clade. Clades within the subgenus Iberozabrus are similar (but not coincident) to those ones obtained by distance and maximum likelihood methods.

\section{DISCUSSION}

\section{The monophyly of the genus Zabrus}

All the trees indicate that Zabrus species make up a monophyletic group with high BT and IBT values, whose sister taxon is still uncertain, although all the analyses indicate either Amara or Curtonotus (currently regarded as a subgenus of Amara) as the sister group (Fig. 1). This corroborates the conclusions of a karyotype analysis (Galián et al., 1991; Sánchez-Gea et al., 2000), and those based on morphology and geographic distribution of taxa (Andújar \& Serrano, 2001), and the structure of the female genitalia (Ortuño et al., 2003). Amara and Curtonotus are Holarctic taxa, whereas Zabrus is a Mediterranean genus. This suggests that Zabrus originated from Amara-like ancestors after the separation of the Eurasiatic and North American plates, which started at the beginning of the Cenozoic Era, about $65 \mathrm{MY}$ ago.

\section{The monophyly of the subgenera of Zabrus endemic to the Iberian Peninsula}

In all analyses the four subgenera endemic to the Iberian Peninsula, Epomidozabrus, Euryzabrus, Platyzabrus and Iberozabrus make up a monophyletic group (Fig. 1), which is separated from the species of the subgenera from the Canary Islands (Macarozabrus: Z. laevigatus), Morocco (Polysitus: Z. guildensis), the Eastern Mediterranean region (Pelor: various species) and the widespread subgenus Zabrus (Z. ignavus and Z. tenebrioides).

This is associated with the poor dispersal power of the genus, as only species of the subgenus Zabrus have fully developed wings and are able to fly. With the exception of this subgenus, the other subgenera are restricted to particular areas of the Mediterraneo-Turanian region. In terms of morphology and geography the large subgenus Pelor lacks consistency, and so Ganglbauer (1915), and more recently Freude $(1986,1988,1989,1990)$ attempted to split this subgenus into four species-groups with better congruency. Andújar \& Serrano (2000) indicated that Pelor is probably polyphyletic and should be divided into monophyletic units, and proposed the subgenera Italozabrus and Himalayozabrus. Nonetheless, the few species of Pelor included in our analysis are probably close 
relatives (they were collected in Bulgaria, Greece and Turkey) and thus it is not surprising that all of them are grouped in the same clade.

The Iberian subgenera with few species, Epomidozabrus, Euryzabrus and Platyzabrus seem to share a common ancestor (Fig. 1), and their sister group is the larger subgenus Iberozabrus (22 species). High BT and IBT values support both clades. Epomidozabrus, Euryzabrus and Platyzabrus are not interspersed within the species of Iberozabrus, as indicated by the phylogenetic analysis based on morphological characters (Andújar \& Serrano, 2001). The presence of three extra adenines at the end of the tRNAleu sequence of species of the subgenus Iberozabrus supports the monophyletic nature of this subgenus. As these three subgenera are restricted to the oldest massifs on the Peninsula (mountains of Galicia, the Cantabrian Chain and the Sistema Central Chain, respectively), they may represent the first evolutionary radiation of the genus Zabrus in Iberia.

\section{The limits and internal relationships of Iberozabrus}

Ganglbauer (1915) and Freude (1986) placed some of the Iberozabrus species in the large subgenus Pelor group I (Z. consanguineus, $Z$. theveneti, Z. angustatus, $Z$. gravis, Z. silphoides, Z. rotundatus). Jeanne (1968) included these species in Iberozabrus, a decision corroborated by our study and that using karyotypic data (Galián et al., 1991). These conclusions again emphasize the congruence between the monophyly of subgenera of Zabrus and their geographic distribution.

Distance, maximum likelihood and maximum parsimony analyses indicate (Fig. 2) that Iberozabrus includes clades that coincide in part with the seven species-groups proposed by Andújar \& Serrano (2001) on the basis of morphology and geographic distribution. These groups are listed in Appendix 2 and their geographic distributions are shown in Fig. 3.

The species-group 1 is made up exclusively of Zabrus (Iberozabrus) consanguineus. It is the most distinct species in the subgenus and is related to the subgenus Epomidozabrus by the three phylogenetic analyses (Fig. 1). This relationship is congruent with their morphology and geographic distribution as $Z$. consanguineus is the only species of the genus that occurs in the Cantabrian Mountains, which are adjacent to the Galician Mountains occupied by Epomidozabrus. All the data suggest that this species belongs to a lineage related to Epomidozabrus, which should be placed outside Iberozabrus, perhaps in a new subgenus as suggested by Andújar \& Serrano (2001).

The species-groups supported by this study are $Z$. urbionensis (species-group 2), Z. angustatus and $Z$. theveneti (species-group 5, Betic Mountains), and Z. obesus and $Z$. eserensis (species-group 7, Pyrenees). However, speciesgroups 3 (curtus-group), 4 (seidlitzi-group) and 6 (ambiguous-group) are not well supported (Fig. 2).

The species of the curtus-group make up two unrelated terminal clades, one formed by $Z$. curtus and Z. marginicollis, and the other by $Z$. castroi and $Z$. vasconicus together with some members of the ambiguus-group. This group has a pronotum with an emarginate posterior basis and outward protruding posterior angles, and a geographic distribution mainly centred in the Sistema Ibérico and the Basque Mountains (Andújar \& Serrano, 2001). As the shape of the pronotum is an adaptive character it is possible that this group is polyphyletic based on a homoplasic character. Likewise, the curtus-group shows a heterogeneous geographic pattern (Fig. 3) as it occupies a broad altitudinal range from the coast ( $Z$. inflatus, not sequenced, inhabits the French Landas) to the montane belt (the preferred altitude) and the high mountains. In the north it reaches the Fontainebleau forest close to Paris, and in the south the southern border of the Sistema Ibérico. Further studies are needed to test the monophyly of the group and reconstruct its complex evolution.

The species of the seidlitzi-group make up three terminal clades, one includes the $Z$. seidlitzi species complex, another $Z$. estrellanus and $Z$. galicianus, and a third Z. coiffaiti and Z. silphoides silphoides, a species of the ambiguus-group. This indicates that this group differentiated in two areas, the oriental and central Sistema Central, and the western Sistema Central (Portugal, Serra da Estrela) plus the mountains of Galicia. In the east the range occupied by the subspecies of $Z$. seidlitzi (the sierras of Guadarrama and Gredos) partially overlaps that of $Z$. coiffaiti and its molecular sister taxa $Z$. silphoides (Sierra de Gredos). If the relatedness of $Z$. coiffaiti and $Z$. silphoides is corroborated by other characters then the morphological characters used to place these species in different species-groups (lateral margin of elytron widened or narrow near humeral region, pronotum sides straight or rounded, posterior angles almost square or obtusely rounded) are not entirely reliable. To the northeast $Z$. cameranus and Z. gibbulus (not sequenced) are also putative members of this species-group (Andújar \& Serrano, 2001). In the west area Z. estrellanus (Serra da Estrela) is closely related to Z. galicianus (mountains of Galicia). These two areas are faunistically related (Novoa et al., 1996).

The ambiguus-group was defined on the basis of a pronotum with rounded sides and a geographic distribution centred in the southern half of the Iberian Peninsula, in contrast to the northern distribution of most of the other species-groups of Iberozabrus. It includes Z. ambiguus, a species with a large altitudinal range from the Southern Meseta to the high sierras (e.g., Sierra Nevada). This species shows incipient morphological differentiation, which has resulted in the description of taxa currently regarded as synonyms (Andújar \& Serrano, 2001). Z. rotundatus is morphologically a sibling species of $Z$. ambiguus restricted to the western Betic sierras (Sierra de Ronda), but the phylogenetic trees indicate that these taxa are distantly related (Fig. 2). Z. gravis is a lowland species related to $Z$. ambiguus based on the characters investigated. Finally, Z. silphoides should be removed from this species-group, because all of the consensus trees place this species close to $Z$. coiffaiti (a member of the seidlitzigroup). That the geographic area of $Z$. silphoides (Northern Meseta) and Z. coiffaiti (Sierra de Gredos) meet at the upper limit of the montane belt on the north 
side of the Sierra de Gredos, makes this relationship more plausible.

Our analysis of a mitochondrial fragment suggests more complex relationships within the subgenus Iberozabrus than the morphology and geographic distribution. As noted by Andújar \& Serrano (2001) the phylogenetic value of morphological characters is low, mostly because they are adaptive and subject to convergence and homoplasy. The reconstruction of the phylogeny of this taxon is also hindered by changes that occurred on the Iberian Peninsula during the Miocene due to alpine tectonics and climatic oscillations. The parallel orientation of Iberian massifs, which are connected by the Sistema Iberico Mountains in a North-South direction (Fig. 3), has probably favoured repeated periods of isolation and speciation followed by dispersal and colonisation. This evolutionary scenario makes it more difficult to reconstruct the phylogeny of Iberozabrus than that of the genus Calathus on the Macaronesian Archipelagos (Emerson et al., 1999, 2000). The Macaronesian islands are strong barrier to dispersal, which explains why each island has its own endemic Calathus (Machado, 1992). Only Tenerife, one of the oldest islands, has probably experienced more than one colonisation event and a complex intraisland radiation, giving rise to different species-groups of Calathus (incidentally, there are two Zabrus species on Tenerife and one on Gran Canaria).

In summary, there is a lack of congruence between the different data sets for the subgenus Iberozabrus, which might be solved in the future by sequencing additional genes and surveying other morphological, genomic and ecological characters.

ACKNOWLEDGEMENTS. This study was financed by projects PB-98-0402 and PB-95-0235, of the Dirección General de Investigación y Científica of the Spanish Government. Thanks are due to the many colleagues that collected beetles for us: J.L. Lencina, A. Andújar, C. Andújar, A.S. Ortiz, B. Fernández, E.M. Martínez (Dept. of Zoology, Murcia), C. Mejuto (Pontevedra), J.P. Zaballos (Univ. of Madrid), D. Mossakowski (Univ. of Bremen), A. Machado (Tenerife), B. Gueorguiev (Natl. Mus. Nat. History, Sofia), L. Penev and I. Stoyanov (Central Lab. General Ecology, Sofia), A. Casale (Univ. Sassari, Italy), and A Koçak and M. Kemal (Univ. of Van, Turkey). P. de la Rúa, E.M. Martínez, F. Cánovas and J. Gómez-Zurita (Dept. of Zoology, Murcia) made valuable comments on the manuscript and helped with the laboratory procedures. The final manuscript was much improved by comments of two anonymous referees.

\section{REFERENCES}

AndúJar A. \& Serrano J. 2000: Taxonomic notes on the genus Zabrus (Coleoptera, Carabidae, Zabrini). Boln. Asoc. Esp. Entomol. 24: 185-193.

AndúJar A. \& Serrano J. 2001: Revisión y filogenia de los Zabrus Clairville, 1806 de la península Ibérica (Coleoptera, Carabidae). Monografías de la Sociedad Aragonesa de Entomología, no. 5, Zaragoza, 90 pp.

Avise J.C. 2000: Phylogeography. The History and Formation of Species. Harvard University Press, Cambridge, $447 \mathrm{pp}$.

Emerson B.R., Oromí P. \& Hewitt G.M. 1999: MtDNA phylogeography and recent intra-island diversification among Canary Island Calathus beetles. Mol. Phyl. Evol. 13: 149-158.
Emerson B., Oromí P. \& Hewitt G. 2000: Interpreting colonization of the Calathus (Coleoptera: Carabidae) of the Canary Islands and Madeira through the application of the parametric bootstrap. Evolution 54: 2081-2090.

Freude H. 1986: Revision der zur (?) Gattung "Zabrus" Clairville, 1806 gehörenden Arten mit Bestimmungstabellen (Col. Carabidae). Atti Mus. Civ. Stor. Nat. Trieste 39: 133-150.

Freude H. 1988: Revision der zur (?) Gattung "Zabrus" Clairville, 1806 gehörenden Arten mit Bestimmungstabellen (Col. Carabidae). 2. Teil. Atti Mus. Civ. Stor. Nat. Trieste 41: 133-142.

FREUDE H. 1989: Revision der zur (?) Gattung "Zabrus" Clairville, 1806 gehörenden Arten mit Bestimmungstabellen (Col. Carabidae). 3. Teil. Atti Mus. Civ. Stor. Nat. Trieste 42: 71-153.

Freude H. 1990: Revision der zur (?) Gattung "Zabrus” Clairville 1806 gehörenden Arten mit Bestimmungstabellen (Col. Carabidae). 4. Atti Mus. Civ. Stor. Nat. Trieste 43: 329-364.

Galián J., Ortiz A.S. \& Serrano J. 1991: Amara and Zabrus, two different patterns of karyotypic evolution (Coleoptera, Carabidae). Caryologia 44: 75-84.

Galián J., De la Rúa P., Serrano J., Juan C. \& Hewitt G.M. 1999: Phylogenetic relationships in Iberian Scaritina (Coleoptera: Carabidae) inferred from mitochondrial COI sequences and karyotype analysis. J. Zool. Syst. Evol. Res. 37: 85- 92.

GANGlbauer L. 1915: Revision der Gattung Zabrus Clairv. Münch. Koleopt. Z. 4: 87-137.

Howland D.E. \& HewitT G.M. 1995: Phylogeny of the Coleoptera based on mitochondrial cytocrome oxidase I sequence data. Insect Mol. Biol. 4: 203-215.

Jeanne C. 1968: Carabiques de la Péninsule Ibérique (9ème note). Act. Soc. Linn. Bordeaux (A) 105(8): 1-22.

Kumar S., Tamura K., Jakobsen I.B. \& Nei M. 2001: MEGA2: Molecular Evolutionary Genetics Analysis software. Bioinformatics 17: 1244-1245.

Machado A. 1992: Monografia de los carábidos de las Islas Canarias (Insecta, Coleoptera). Instituto de Estudios Canarios, La Laguna, 734 pp.

MadDison W.P. \& MAdDIson D.R. 1992: MacClade. Analysis of Phylogeny and Character Evolution, v.3. Sinauer Associates Inc., Sunderland, 398 pp. + computer disk.

Martínez-Navarro E.M., Galián J. \& Serrano J. (in press): Phylogeny and molecular evolution of the tribe Harpalini (Coleoptera, Carabidae) inferred from mitochondrial cytochrome-oxidase I. Mol. Phyl. Evol.

Novoa F., Mariño J. \& Lombardero J. 1996: Los Carabidae (Coleoptera) de los montes del Invernadeiro (NO. Península Ibérica) y algunas consideraciones sobre la carabidofauna de las Montañas Orientales de Galicia. Bol. R. Soc. Esp. Hist. Nat. (Biol.) 92: 167-175.

Oosterbroek P. \& Arntzen J.W. 1992: Area-cladograms of Circum-Mediterranean taxa in relation to Mediterranean paleogeography. J. Biogeogr. 19: 3-20.

Ortuño V.M., Serrano J., Andujar A. \& Lencina J.L. 2003: The female genitalia of the genus Zabrus (Coleoptera: Carabidae: Zabrini). I. The general structure and the subgenera Zabrus, Euryzabrus, Platyzabrus and Epomidozabrus. Eur. J. Entomol. 94: 115-121.

Posada D. \& Crandall K.A. 1998: Modeltest: testing the model of DNA substitution. Bioinformatics 14: 817-818

Sambrook J., Fritsch E.F. \& Maniatis T. 1989: Molecular Cloning: A Laboratory Manual. Vol. 3. 2nd ed. Cold Spring Harbor Laboratory Press, Cold Spring Harbor.

SÁnchez-Gea J.F., SerRano J. \& Galián J. 2000: Variability in rDNA loci in Iberian species of the genus Zabrus (Coleoptera: 
Carabidae) detected by fluorescence in situ hybridization. Genome 43: 22-28.

Simon C., Frati F., Beckenbach A., Crespi B., Liu H. \& Flook P. 1994: Evolution, weighting, and phylogenetic utility of mitochondrial gene sequences and a compilation of conserved polymerase chain reaction primers. Ann. Entomol. Soc. America 87: 651-701.

Swofford D.L., Olsen G.L., Waddell P.J. \& Hillis D.M. 1996: Phylogenetic Inference. In Hillis D.M., Moritz C. \& Mable
B.K. (eds): Molecular Systematics. 2nd ed. Sinauer Associates, Sunderland, pp. 407-514.

Thompson J.D., Higgins D.G. \& Gibson T.J. 1994: CLUSTAL $\mathrm{W}$ : improving the sensitivity of progressive multiple sequence alignment through sequence weighting, positions-specific gap penalties and weight matrix choice. Nucl. Acids Res. 22: 4673-4680.

Walsh P.S., Metzeer D.A. \& Higuchi R. 1991: Chelex 100 as a medium for simple extraction of DNA for PCR-based typing from forensic material. Biotechniques 10: 506-512.

APPENDIX 1. Localities (major mountain massifs or lowland areas) from which Zabrus and related taxa sequenced in this study were collected. SP Spain, PT Portugal, MO Morocco, CI Canary Islands, GR Greece, BU Bulgaria, TR Turkey. Sampling dates and precise data of localities can be obtained upon request.

\begin{tabular}{|c|c|c|}
\hline Taxon & Number of individuals & Localities \\
\hline \multicolumn{3}{|l|}{ Tribe Zabrini } \\
\hline \multicolumn{3}{|l|}{ Genus Zabrus } \\
\hline \multicolumn{3}{|l|}{ subgenus Epomidozabrus Ganglbauer, 1915} \\
\hline flavangulus Chevrolat, 1840 & 2 & Serra da Estrela, PT \\
\hline \multicolumn{3}{|l|}{ subgenus Euryzabrus Ganglbauer, 1915} \\
\hline pinguis Dejean, 1831 & 1 & SW coast of Galicia, SP \\
\hline \multicolumn{3}{|l|}{ subgenus Iberozabrus Ganglbauer, 1915} \\
\hline \multirow[t]{3}{*}{ ambiguus Rambur, 1838} & 1 & NW Betic Mountains-1, SP \\
\hline & 1 & NW Betic Mountains-2, SP \\
\hline & 1 & Sierra Nevada, SP \\
\hline angustatus Rambur, 1838 & 1 & Sierra Nevada, SP \\
\hline \multirow[t]{2}{*}{ castroi Martínez y Saez, 1873} & 1 & S Sistema Ibérico, SP \\
\hline & 2 & E Sistema Central, SP \\
\hline coiffaiti Jeanne, 1970 & 5 & Sierra de Gredos, SP \\
\hline consanguineus Chevrolat, 1865 & 1 & W Cantabrian Mountains, SP \\
\hline curtus arragonensis Heyden, 1883 & 1 & S Sistema Ibérico, SP \\
\hline curtus neglectus Schaum, 1864 & 3 & N Sistema Ibérico, SP \\
\hline eserensis C. Bolívar, 1918 & 2 & Central Pyrenees, SP \\
\hline estrellanus Heyden, 1880 & 2 & Serra da Estrela, PT \\
\hline galicianus Jeanne, 1970 & 2 & SE Mountains of Galicia, SP \\
\hline gravis Dejean, 1828 & 1 & Southern Meseta, SP \\
\hline marginicollis Dejean, 1828 & 1 & Northern Meseta, SP \\
\hline obesus Audinet-Serville, 1821 & 2 & Central Pyrenees, SP \\
\hline rotundatus Rambur, 1838 & 1 & W Betic Mountains, SP \\
\hline \multirow{2}{*}{ seidlitzi gredosanus Jeanne, 1970} & 2 & Sierra de Gredos-1, SP \\
\hline & 1 & Sierra de Gredos-2, SP \\
\hline seidlitzi laurae Toribio, 1989 & 5 & E Sierra de Guadarrama, SP \\
\hline seidlitzi seidlitzi Schaum, 1864 & 1 & C Sierra de Guadarrama, SP \\
\hline \multirow[t]{2}{*}{ silphoides silphoides Dejean, 1828} & 1 & Northern Meseta, SP \\
\hline & 2 & Sierra de Francia, SP \\
\hline theveneti Chevrolat, 1874 & 2 & NW Betic Mountains, SP \\
\hline urbionensis Jeanne, 1970 & 1 & N Sistema Ibérico, SP \\
\hline vasconicus Uhagón, 1904 & 2 & Basque Mountains, SP \\
\hline \multicolumn{3}{|l|}{ subgenus Macarozabrus Ganglbauer 1915} \\
\hline laevigatus Zimmermann, 1831 & 3 & Tenerife, CI \\
\hline \multicolumn{3}{|l|}{ subgenus Pelor Bonelli, 1810} \\
\hline balcanicus balcanicus Heyden, 1883 & 1 & W Rhodopi Mountains, BU \\
\hline balcanicus rhodopensis Apfelbeck, 1904 & 2 & S Pirin Mountains, BU \\
\hline spinipes spinipes Fabricius, 1798 & 1 & W Rhodopi Mountains, BU \\
\hline graecus graecus Dejean, 1828 & 2 & Micenas, GR \\
\hline melancholicus melancholicus Schaum, 1864 & 1 & Ak Mountains, TR \\
\hline rotundicollis Ménétriés, 1836 & 2 & Tahtali Mountains, TR \\
\hline trinii trinii Fischer von Waldheim, 1817 & 2 & Musgüney Mountains, TR \\
\hline \multicolumn{3}{|l|}{ subgenus Platyzabrus Jeanne, 1970} \\
\hline constrictus Graells, 1858 & 2 & Sierra de Béjar, SP \\
\hline pecoudi Colas, 1942 & 1 & Sierra de Gredos, SP \\
\hline \multicolumn{3}{|l|}{ subgenus Polysitus Zimmermann 1831} \\
\hline guildensis Alluaud, 1932 & 1 & Fes, MO \\
\hline \multicolumn{3}{|l|}{ subgenus Zabrus Clairville, 1806} \\
\hline ignavus ignavus Csiki, 1907 & 1 & NW Betic Mountains, SP \\
\hline & 2 & Southern Meseta, SP \\
\hline
\end{tabular}


Genus Amara

subgenus Amara Bonelli, 1810

similata Gyllenhal, 1810

subgenus Amathitis Zimmermann, 1832

rufescens Dejean, 1829

subgenus Camptocelia Jeanne, 1942

eximia Dejean, 1828

subgenus Celia Zimmermann, 1832

ingenua Duftschmid, 1812

subgenus Percosia Zimmermann, 1832

equestris Duftschmid, 1812

subgenus Leironotus Ganglbauer 1892

rotundicollis Schaufuss, 1862

Genus Curtonotus

aulicus Panzer, 1796

Alicante, SP

1

Murcia, SP

Tribe Sphodrini

Calathus (Neocalathus) rotundatus rotundatus Jacquelin du Val, 1857

Platyderus (Platyderus) lusitanicus lusitanicus Dejean, 1828

NW Betic Mountains, SP

1

Southern Meseta, SP

1

SE Mountains of Galicia, SP

SE Mountains of Galicia, SP

W Rhodopi Mountains, BU

Tribe Platynini

Agonum (Agonum) nigrum Dejean, 1828

Paranchus albipes Fabricius 1792

Southern Meseta, SP

Málaga, SP

Tribe Pterostichini

Orthomus velocissimus pardoi Mateu, 1957

Málaga, SP

APPENDIX 2. Species-groups of Iberozabrus postulated by Andújar \& Serrano (2001) on the basis of morphological and geographic distribution. * Taxa not sequenced.

Group 1. Zabrus consanguineus Chevrolat

Group 2. Zabrus urbionensis Jeanne

Group 3. Z. curtus Audinet-Serville, Z. castroi Martínez, Z. notabilis Martínez*, Z. vasconicus Uhagón, Z. marginicollis Dejean and $Z$. inflatus Dejean*

Group 4. Z. seidlitzi Schaum, Z. estrellanus Heyden, Z. galicianus Jeanne, Z. coiffaiti Jeanne, Z. cameranus Arribas* and Z. gibbulus Jeanne*

Group 5. Z. theveneti Chevrolat and Z. angustatus Rambur

Group 6. Z. ambiguus Rambur, Z. rotundatus Rambur, Z. gravis Dejean and Z. silphoides Dejean

Group 7. Z. obesus Audinet-Serville and Z. eserensis C. Bolívar 